\title{
Is there a renaissance of radical social work?
}

Radical and critical social work are the focus of this special issue of Aotearoa New Zealand Social Work. For this issue we commissioned shorter commentary pieces by Iain Ferguson and Linda Briskman and an extended review by Mike O'Brien. We called for articles which addressed the agenda for renewed interest in radical and critical approaches. Simply defined, radical social work usually includes those approaches identified as Marxist, socialist, structural, feminist, anti-racist, anti-disablist and antioppressive (see for instance, Baines, 2006; Collins, 1986; Dominelli \& Campling, 2002; Ife, 2012; Lavalette, 2011; Mendes, 2017; Mullaly, 2007). Class-based domination and oppression are crucial to radical social workers (Lavalette, 2011; Mendes, 2017; Mullaly, 2007). Critical social work overlaps with but also differs from radical social work in its appreciation of post-modern and post-structural ideas in understanding how power, domination, control and resistance can operate (see Allan et al., 2003; Beddoe \& Maidment, 2009; Briskman, 2007; Ife, 2012; Morley, MacFarlane, \& Ablett 2014). Across the radical and critical social work spectrum, there is a shared interest in power relations and the power of language to reproduce social inequality; the differential impact of social inequality on particular groups; the goals of social transformation; and the possible forms of resistance, given contexts and resources.

Critical and radical social workers are well aware that neoliberal global capitalism has intensified the problems of inequality in aggressive ways. Universities and public welfare organisations alike have been corporatised and managerialised creating work cultures that increasingly expect conformity and compliance (Fraser \& Taylor, 2016). Under neoliberal global capitalism, the gulf between the rich and poor has widened (Mendes, 2017; Rashbrooke, 2013), and human rights abuses are plentiful, so much so that it is tempting for social workers, new and old, to adopt fatalistic positions about injustice and oppression. It is tempting to think that how life is now is how it has always been, and always will be, that nothing can be done, that, to quote the slogan of Margaret Thatcher, "There is no alternative".

Rather than surrendering to a politics of despair (Mullaly, 2001), we take the view that social workers need to re/politicize their purpose. In a recent article entitled "Taking a political stance in social work" David McKendrick and Stephen Webb (2014, p.359) wrote:

We are persuaded, often by ourselves, that radical politics is futile. So we tend towards compromise, resignation and indifference. Mainstream liberal social work discourse has a tendency to limit and even dislodge our experience of what is important and urgent. It tries to persuade us that social work is politically neutral. Thus, it can take over our voice and regulate our feelings into ones of apathy or disinterest.

In this special issue many contributors urge social workers not to shut down through political apathy and disinterest. They urge us not to fall into the trap of hyper-individualising social problems. For instance, in his commentary "The new social work radicalism" Iain Ferguson points out the growing obsession with psychological explanations for poverty. Neoliberalism has made it hard to even imagine what an egalitarian society might look like. The drive for pragmatism can also make the search for 'radical' (or transformative) alternatives feel so
AOTEAROA NEW ZEALAND SOCIAL WORK 29(2), 1-5. 
out-of-step with others. Yet, this is precisely what we must do. We must be part of a movement that re-imagines our contexts and presses for changes to more closely resemble the values of democracy, fairness and equality. Linda Briskman implores us to do exactly this in her commentary article "Revitalising radical social work".

Critical, radical and structural social workers appreciate that unemployment, poverty and homelessness are debilitating social problems in many people's lives (Lavalette, 2011; Mullaly, 2007; Morley et al., 2014). Yet, these issues are often reduced to individual deficits, either by ignoring them altogether or diminishing their impact. To quote Ferguson in this issue, "...psycho-compulsion usually means the use of positive psychology approaches to encourage an 'improved' attitude to finding work". He notes the growing but still relatively small movement of 'radical' social workers. We say 'radical', in inverted commas, because many of the ideas and activities purported to be radical are designed to pursue social equality, which should not be radical to social workers. For those wondering if neoliberal social work has a place alongside other forms we say that it cannot. Managerialism, consumerism and the privatisation of social work - the three pillars of neoliberalism-cannot deliver social work's commitment to social justice to 'end users' or workers. Neoliberalism is not designed to be fair, just, empathic or even compassionate. To quote Ferguson again:

...neoliberal social work challenges the very essence of social work as a valuebased, relationship-based profession. In its place it offers a technical occupation whose primary concerns are with rationing scarce services [and] controlling 'troublesome families'...

Furthermore, while we work often at the local and national levels, Briskman argues that global alliances of resistance are necessary to oppose the pathologisation of those who experience social problems. In his extended review of Philip Mendes' (2017) book "Australia's welfare wars: The players, the politics and the ideologies" Mike O'Brien rightly speaks of the willful disregard of structural causes of rising poverty for so many across the world, in and beyond affluent Western countries; also of the convergence of so many major political parties to neoliberal welfare austerity. In this climate, social workers are challenged to do more than put band-aids on the injuries caused by cuts to incomes, social housing and other basic services.

From the Auckland Action Against Poverty (AAAP), Alastair Russell challenges social work's pursuit of professionalism, particularly during a time of 'no politics' funding embargoes on NGOS with government contracts. In his commentary, "Competent solidarity: the alternative for professional social work", Russell argues that:

Professional social work is taught as if it exists within a political vacuum, largely devoid of class analysis and is incapable of addressing issues of poverty and oppression...Within social work there is a clear emphasis on working with individuals who have a problem, who are deemed to be dysfunctional. In this context, it is easy to ignore the need for social change.

As an experienced supervisor of social work students on field placements, Russell calls for a paradigm shift where social workers place political purpose at the centre of their thinking. It is through this politicised engagement that social workers can then stand alongside the impoverished and oppressed, rather than above or apart from them. Providing examples from the AAAP, he shows how benefits advocacy-or advocacy undertaken to ensure communities receive their full welfare entitlements-is an important way to demonstrate competent solidarity. Campaigns to stop income support sanctions leveled against the poor are another good example of competent solidarity in action. 
In the first of the major articles in the special issue, Christine Morley and Philip Ablett examine major trends in wealth and income inequality (both globally, and specifically in Australia and Aotearoa New Zealand) and the social work responses to them. They argue that understanding the impact of economic inequality must be at the core of social work education and practice, with a call to foster practitioners' capacity for critical reflection, policy practice and political activism.

In the next article, Hannah Blumhardt discusses the work by the organization, All Together in Dignity to Overcome Poverty (ATD), undertaken with families in poverty. She reports on findings from interviews focused on ATD Fourth World's practice approach in England. Three distinctive aspects emerged from the study: (1) acknowledging and addressing the impact of poverty; (2) maximising collaborative practice; and (3) adopting relational approaches to service provision. Blumhardt then contrasts these aspects with state child protection policies in Aotearoa New Zealand and England.

From Carleton University in Canada, Filipe Duarte advocates reshaping ideology in social work from a critical perspective; one informed by analyses of materialism, and with reference to an overtly politicized notion of social justice,

By questioning the relationship between ideology and the power of the dominant class, social work has the opportunity to achieve a new momentum for social and political action in accordance with its own values and commitments.

For Duarte, any social work described as radical must recognize class-based oppression and its pernicious effects. Questions about who has effective control over resources cannot be sidestepped. As he contends, economic systems are not, and should not be treated by social workers as neutral. There is plenty of evidence demonstrating how neoliberal capitalism privileges ruling elites and hurts the oppressed and marginalized. As he argues, social work education needs to ensure students continue to be politicized about class-based domination, and the materialist structures that reproduce it.

Using the principles of radical analysis Angelika Papadopoulos explores the current discourses of radical social work. She concludes that the radical strategy "can no longer take the form of 'speaking truth to power', for power no longer feels obliged to listen". She analyses the positioning of radical social work in the post 9/11 era and challenges the reliance of metanarratives that imagine one end-point for radical action in which everything is made better. She argues for a much more rigorous analysis of the meaning of social work core concepts, such as social justice and empowerment.

In the next article, Chihota argues for the inclusion of Critical Language Awareness (CLA) in social work education, to enable students to appreciate the nexus between power/language/social structure and learn how language can be used to reproduce social inequality. Power radiates through our choice of terms and turns of phrase, and as Chihota implies, we should not hide or deny our use of power,

For instance, the text types (or genres) chosen by communicators shape how communicative events are construed and experienced (Fairclough, 2009). To illustrate, inviting a client for "a chat" raises very different expectations from asking them to attend "an interview" or "an assessment".

Chihota offers all readers the chance to reflect, more closely, on the use of language to construct social subjectivities and negotiate power relations in very unequal social contexts. Some useful suggestions are also provided for social work educators looking for ways to include CLA in their teaching. 


\section{Introduction to the general section}

In this general section of this issue, we are pleased to present five articles which report social work research from Aotearoa New Zealand and Australia. In the first article Ang Jury, Natalie Thorburn and Ruth Weatherall report findings from a survey aimed to understand the experiences and effects of economic abuse for women in Aotearoa New Zealand, particularly in relation to methods of coercive control. The researchers found that gender stereotypes were used to justify the appropriation of women's resources and removal of women's financial autonomy. The authors have translated these findings into risk matrices to assist with the identification of economic abuse.

In the second article, the authors' focus is on the experiences of older men with haemophilia in Aotearoa New Zealand. Support services, particularly the roles that social workers could play in facilitating wellbeing, are explored by Sarah Elliott, Kelsey Deane and Barbara Staniforth, who note the complexities associated with this aging population.

In another article with a health focus, cultural sensitivity in hospital-based social work services is the topic of Doris Testa's report of a small qualitative study in Australia. Testa calls for the social workers to continually explore their own and their clients' multiple cultural identities, seeking unique narratives and establishing processes that recognize the client as the expert.

A current issue for critical educators is how different demographics within the lesbian, gay, bisexual, transgender, intersex, queer (LGBTIQ) community experience health policies and services. Margaret Pack and Peter Brown present a literature view and teaching reflections as evidence for an explicitly anti-oppressive approach to be applied to the education of professionals who work with elders identifying as gender and/or sexually diverse.
Finally, in this issue, Stefanie Döbl, Liz Beddoe and Peter Huggard report on a study of social work in primary healthcare settings in Aotearoa New Zealand. While social work has been well established in public hospitals and community health services for many decades, less is known about the experiences of social workers integrated in primary health care practices. This article reports on a small, qualitative research project that explored the perceptions of key stakeholders about social work integration into primary health care.

Together, the collection of works in this special edition is a timely reminder of the need for social workers, to engage with critical questions about power, rights and justice and contemplate 'radical' alternatives for the many communities we serve. Whether working at the micro, mezzo or macro levels social workers has always promoted the prospect of positive change. Now, more than ever, our practice must be infused with radical hope and sustain the belief that there are alternatives, that other worlds are possible.

\section{References}

Allan, J., Pease, B., \& Briskman, L. (2003). Critical social work: An introduction to theories and practices. Crows's Nest, NSW: Allen and Unwin.

Baines, D. (Ed.) (2006). Doing anti-oppressive practice: Building transformative, politicized social work. Winnipeg, Canada: Fernwood.

Beddoe, E., \& Maidment, J. E. (2009). Mapping knowledge for social work practice: Critical intersections. South Melbourne, VIC: Cengage Learning.

Briskman, L. (2007). Social work with Indigenous communities. Sydney, NSW: The Federation Press.

Collins, B. G. (1986). Defining feminist social work. Social Work, 31(3), 214-219.

Dominelli, L., \& Campling, J. (2002). Anti-oppressive social work theory and practice. Basingstoke, UK: Palgrave Macmillan.

Fraser, H., \& Taylor, N. (2016). Neoliberalization, Universities and the public intellectual: Species, gender and class and the production of knowledge. Basingstoke, UK: Palgrave Macmillan.

Giroux, Henry A. (2005). When hope is subversive. Tikkun, 19(6), 38-39. Retrieved from: https://www.henryagiroux.com/ online_articles/Tikkun\%20piece.pdf

Ife, J. (2012). Human rights and social work: Towards rights-based practice. Port Melbourne VIC: Cambridge University Press. 
Lavalette, M. (Ed.). (2011). Radical social work today: Social work at the crossroads. Bristol, UK: Policy Press.

McKendrick, D., \& Webb, S. A. (2014). Taking a political stance in social work. Critical and Radical Social Work 2(3), 357-369. doi:10.1332/204986014x14096553584619

Mendes, P. (2017) Australia's welfare wars: The players, the politics and the ideologies (3rd ed.) Sydney, NSW: UNSW Press

Morley, C., MacFarlane, S., \& Ablett, P. (2014). Engaging with social work: A critical introduction. Port Melbourne, VIC: Cambridge University Press.

Heather Fraser, Liz Beddoe and Neil Ballantyne
Mullaly, B. (2001). Confronting the politics of despair: Toward the reconstruction of progressive social work in a global economy and postmodern age. Social Work Education, 20(3), 303-320.

Mullaly, B. (2007). The new structural social work: Ideology, theory, practice. Toronto, Canada: Oxford University Press.

Rashbrooke, M. (Ed.). (2013). Inequality: A New Zealand Crisis. Wellington, NZ: Bridget Williams Books. 